\title{
The Study of Lead Pollution in Street Dust and Dinking Water Along Arniko Rajmarg of Nepal
}

\author{
Reena Amatya Shrestha " and Babi Kumar Kafle \\ Department of Natural Science (Chemistry), Kathmandu University, Kavre, Nepal. \\ e-mail: reenashrestha@yahoo.com
}

\begin{abstract}
Lead in street dust and drinking water along Arniko Rajmarg (ARM) of Nepal was analyzed. The concentration of lead is found high in the samples those were collected before monsoon and from heavy traffic regions.
\end{abstract}

Keywords: lead, street dust, highways.

\section{Introduction}

Lead is one of the pollutants among heavy metals in the street dust and drinking water. The main source of the environmental lead is tetraethyl- and/ or tetramethyl lead from gasoline. The lead content in gasoline sold in India, Pakistan and Nepal ranges from $0.42-0.82 \mathrm{~g} / \mathrm{L}$, which is among the highest in the world. ${ }^{1}$ Street dust makes a significant contribution to pollution in the Kathmandu Valley. It consists of vehicle exhaust, sinking particles in air, soil dust, house dust and particles carried by water. Top soils and roadside dusts in urban areas are polluted by lead and other heavy metals. ${ }^{2,3}$ The large particles of lead from vehicle emissions deposit close to the road. The rapidly increasing vehicular traffic in the valley is a major contributor to pollution in Kathmandu. Deterioration of public health, especially due to increase in respiratory and skin diseases, has become a serious concern in the Kathmandu valley. Lead concentration in street dust is a good indicator of road pollution. The main objective of this research work is to measure the lead in street dusts and drinking water nearby the ARM highway.

\section{Experimental methods}

* Corresponding author 
The Arniko Rajmarg (highway) (ARM), $113 \mathrm{Km}$ long from Kathmandu Valley to China boarder, was taken as the study sites. There is a regular bus service and it is one of the busiest highways in Nepal. In this study, street dust and water samples were taken in post- and pre- monsoon from five main points along the ARM such as Baneshwor, Thimi, Suryavinayak, Banepa and $28 \mathrm{Km}$ Dhilikhel. Baneshwor is located at the centre of Kathmandu with a heavy traffic. Thimi, Suryabinayak and Banepa bus station are nearly 8, 16 and $26 \mathrm{Km}$, respectively, far from Baneshwor. The $28 \mathrm{Km}$ Dhulikhel is reference point and is $2 \mathrm{Km}$ far from Banepa city. The $0.5 \mathrm{Kg}$ of the dust and $250 \mathrm{~mL}$ of drinking water were collected in the plastic bag and bottle, respectively, with adding nitric acid to maintain the $\mathrm{pH}$ for preservation of metals in water samples.

Dust samples were dried at $100^{\circ} \mathrm{C}$ and sieved through a $0.5-\mathrm{nm}$ sieve stainless steel. Two grams of the dust sample was treated with 1:3 ratios of $\mathrm{HCl}$ and $\mathrm{HNO}_{3}$. The mixture was then refluxed for half an hour. The solution was cooled, filtered and diluted to $50 \mathrm{~mL}$ with distilled water.

The concentration of lead in water sample and solution of the digested dust were measured by using Flame-Atomic Absorption Spectrophotometer (F-AAS).

\section{Results and discussion}

The concentration of lead increased with increasing the population and the number of vehicles used as shown in Fig. 1. The main city centers like Baneshwor, Thimi, Suryabinayak and Banepa have already exceeded the standard tolerance limit for lead in residential dust given by EPA. ${ }^{4}$ There was slight difference in concentration before and after monsoon which is also shown in Fig. 1.

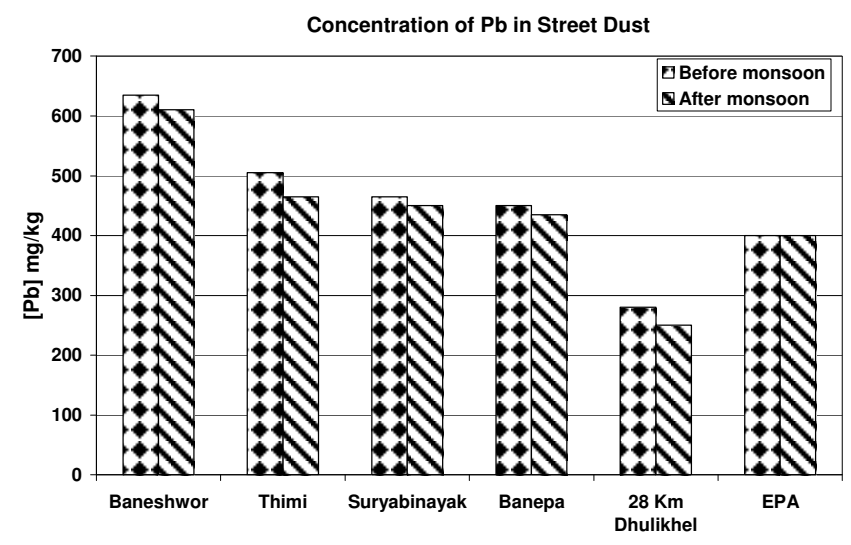

Figure 1: Concentrations of the lead in street dust. 
The drinking water source like tube wells and deep wells nearby the ARM could not escape from the lead pollution. Results showed that water from Baneshwor, Thimi and Suryabinayak had contained 35, 26 and $17 \mu \mathrm{g} / \mathrm{L}$ lead, respectively; those were exceeded from the EPA standard. The lead in drinking water from Banepa was found same as that of EPA standard $(15 \mu \mathrm{g} / \mathrm{L}){ }^{4}$

\section{Conclusions}

It is found that the concentration of lead is high in those areas near from the heavy traffic regions. The concentration of lead was high in the samples, which were collected before monsoon. It is almost clear that the pollution is due to leaded fuels used by the vehicles in Kathmandy Valley.

\section{Acknowledgements}

Grateful thanks to the Department of Natural Sciences (Chemistry), Kathmandu University for providing the research facilities. Authors like to thank Dr. Subhodh Shrama and Dr. Roshan Bajracharya of AEC of Kathmandu University for a help in measuring lead by AAS.

\section{References}

1. R. M. Tripathi, R. Raghunath, A. V. Kumar, V. N. Sastry and S. Sadasivan, Scien. Total Environ., 2001, 267,101.

2. J. W. C. Wong and N. K. Mak, Environ. Technol., 1997, 18,109.

3. E. B. Culbard, I. Thornton J.Watt, M. Wheatley, S. Moorcroft and M. Thompson, J. Environ. Qual., 1988, 17,226.

4. EPA, http://www.epa.gov/lead/ 